COMPUTING APPLICATIONS DIVISION

\title{
CRITICALITY SAFETY CALCULATIONS FOR REGION B OF THE MILISTONE UNIT NO. 2 SPENT FUEL POOL
}

S. M. Bowman

Date Published: January 1993

\begin{abstract}
Prepared for the Fuel Cycle Safety Branch

Office of Nuclear Material Safety and Safeguards

U.S. Nuclear Regulatory Commission under Interagency Agreement No. 1886-8030-4B

FIN B0304
\end{abstract}

\footnotetext{
Prepared by Oak Ridge National Laboratory

Oak Ridge, Tennessee 37831 managed by

MARTIN MARIETTA ENERGY SYSTEMS, INC. for the U.S. DEPARTMENT OF ENERGY under contract DE-AC05-84OR21400
} 
At the request of G. H. Bidinger of the U.S. Nuclear Regulatory Commission (NRC), Oak Ridge National Laboratory (ORNL) staff performed the criticality safety calculations documented herein for the fresh fuel region (Region B) of the Northeast Nuclear Energy Company (NNECO) Millstone Unit No. 2 Spent Fuel Pool. The purpose of these calculations was to verify the results reported by NNECO in their application for revision to the Millstone Unit No. 2 technical specifications. ${ }^{1}$ Data provided by Mr. Bidinger in refs. 1 through 6 served as the basis for these calculations. All calculations were performed with the SCALE-4.1 code system developed at ORNL. Specifically, the CSAS25 criticality control sequence, which executes the BONAMI, NITAWL-II, and KENO V.a codes, was used to perform all $k_{\text {eff }}$ calculations.

The cross sections were processed by BONAMI and NITAWL-II at a tenperature of $20^{\circ} \mathrm{C}$. The water density used in all calculations also corresponded to $20^{\circ} \mathrm{C}$. This is inconsistent with NNECO's statement that their calculations were performed at $4^{\circ} \mathrm{C}$, where the maximum density of water occurs. ${ }^{1}$ However, conversations with the representative of Holtec International who performed the calculations for NNECO verified that all calculations were performed at a temperature and density of $20^{\circ} \mathrm{C}$. Performing the criticality calculations at a temperature of $20^{\circ} \mathrm{C}$ is still conservative, since the spent fuel pool operating temperature will always be greater than $20^{\circ} \mathrm{C}$ (room temperature) due to the decay heat generated by the spent fuel pool. Also, the decrease in reactivity from 4 to $20^{\circ} \mathrm{C}$ was calculated to be less than $0.1 \% \Delta \mathrm{k} / \mathrm{k}$ based on an infinite pin cell calculation performed with the XSDRNPM code.

The KENO V.a geometry model consisted of a $2 \times 2$ array of fuel assemblies with periodic boundary conditions on the sides. A $2 \times 2$ array was used in order to model the three of four fuel assembly loadings used in Region B of the pool. Likewise, the periodic boundary conditions on the $\mathrm{x}$ and $\mathrm{y}$ faces were chosen so that an infinite array of assemblies in a three of four loading could be modeled. A $30-\mathrm{cm}$ water reflector was placed above and below the fuel. The dimensions for the KENO V.a geometry were taken from Fig. 1, supplied by NNECO. ${ }^{5}$ Some minor modifications in the dimensions were made due to the inconsistency of certain dimensions. In particular, based on a half-thickness of the water gap of $0.2552 \mathrm{~cm}$, the distance from the assembly to the edge of the stainless sieel corner should be $12.0141 \mathrm{~cm}$, not 12.0150 . Given that the length of one side of the stainless steel corner is $1-5 / 16 \mathrm{in} .(3.33375 \mathrm{~cm})$, the half length of the water gap should be $8.68035 \mathrm{~cm}$, not $8.6652 \mathrm{~cm}$. As previously stated, these differences are minor and should have a negligible impact on calculational results.

Three cases reported by NNECO in Table 1/B14102/Page 1 of ref. 1 were calculated to yalidate NNECO's results. Calculations for these cases were performed on both the ORNL IBM-3090 mainframe using the quality assurance (QA) controlled version of SCALE-4 and on an IBM RISC/6000 workstation using a copy of the controlled version that has been modified to run on that system. Computing charges on the ORNL mainframe restrict the number of generations that can reasonably be run with KENO V.a. Therefore, only 400 generations with 500 neutrons per generation were run on the ORNL mainframe. An identical number of histories were run on the workstation in order to validate the workstation version. The 


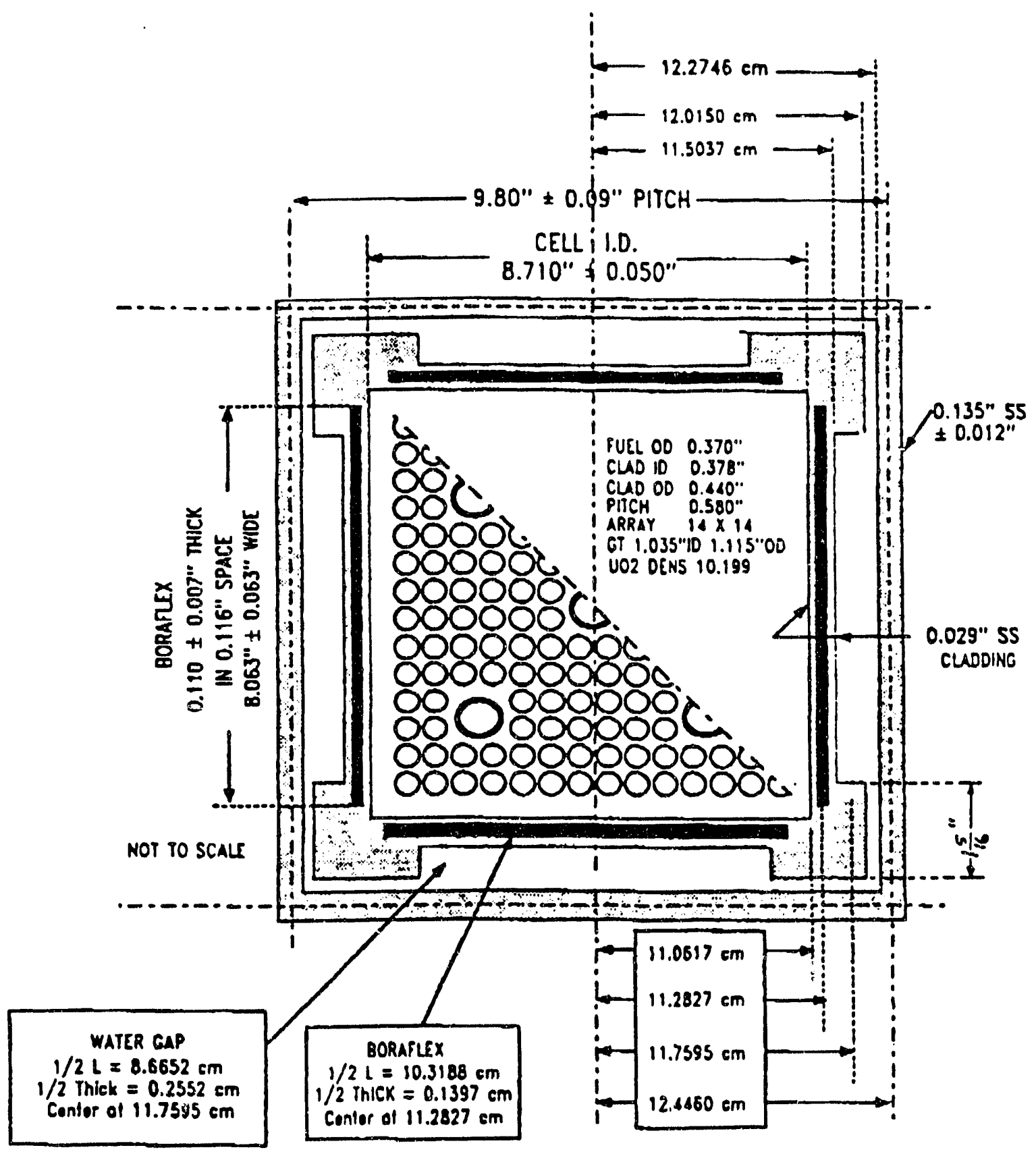

Fig. 1. Cross section of Region 1 cells. 
calculations were performed again on the workstation using 1500 generations in order to improve convergence. These three sets of calculations are presented in Table 1 and show good agreement within the statistical uncertainties of a Monte Carlo code such as KENO V.a. A comparison of our results for 1500 generations to NNECO's results in Table 2 verifies the credibility of NNECO's results. The total bias and uncertainty of 0.0216 applied to NNECO's results for Cases 1 and 3 have been removed from the maximum $k_{\text {eff }}$ reported. This adjustment enables us to compare their calculated results with ours. The maximum $k_{\text {eff }}$ reported by NNECO for Case 5 was actually the calculated value with no bias or uncertainty applied. Therefore, it is reported in Table 2 unchanged.

Two additional calculations were performed with the three of four fuel assembly loading to determine the maximum reactivity due to gaps in the boraflex panels. Gaps of 5.65 in. were placed at the axial midline of each boraflex panel. One calculation assumed no soluble boron in the pool, and the second assumed $800 \mathrm{ppm}$ soluble boron. These calculations were performed twice on the workstation. First, the gaps were assumed to be filled with water. Then the calculations were repeated with the boraflex in the gaps replaced by void. There were 1500 generations in each of these calculations. The results are given in Table 3.

Printer plots generated by KENO V.a to verify the geometry model are provided in Figs. 2 and 3. Figure 2 shows a single fuel assembly with a gap in the boraflex panels that surround it. Figure 3 represents a three of four fuel assembly loading with boraflex panels.

In summary, our calculations (1) verify the credibility of the results reported by NNECO and (2) estimate the maximum $k_{\text {eff }}$ possible, assuming gaps caused by $4 \%$ shrinkage in every boraflex panel in the spent fuel pool. The computer output for these calculations has been transmitted to G. H. Bidinger of the NRC. 
Table 1. ORNL calculated $k_{\text {eff }}$ values on different computers

\begin{tabular}{ccccc}
\hline Case & Description & $\begin{array}{c}\text { ORNL } \\
\text { mainframe } \\
(400 \text { generations })\end{array}$ & $\begin{array}{c}\text { RISC/6000 } \\
\text { workstation } \\
(400 \text { generations })\end{array}$ & $\begin{array}{c}\text { RISC/6000 } \\
\text { workstation } \\
(1500 \text { generations })\end{array}$ \\
\hline 1 & 4 of 4 loading, no gaps & $0.9704 \pm 0.0018$ & $0.9673 \pm 0.0016$ & $0.9692 \pm 0.0009$ \\
3 & 3 of 4 loading, no gaps & $0.8933 \pm 0.0017$ & $0.8890 \pm 0.0017$ & $0.8928 \pm 0.0009$ \\
5 & $\begin{array}{l}3 \text { of } 4 \text { loading, } \\
\text { no boraflex }\end{array}$ & $1.0863 \pm 0.0017$ & $1.0880 \pm 0.0016$ & $1.0895 \pm 0.0008$ \\
\hline
\end{tabular}

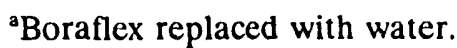

Table 2. Comparison of ORNL and NNECO calculated $\mathrm{k}_{\mathrm{eff}}$ values

\begin{tabular}{cccc}
\hline Case & Description & ORNL $^{\mathrm{a}}$ & NNECO $^{\mathrm{b}}$ \\
\hline 1 & 4 of 4 loading, no gaps & $0.9692 \pm 0.0009$ & 0.9596 \\
3 & 3 of 4 loading, no gaps & $0.8928 \pm 0.0009$ & 0.8897 \\
5 & 3 of 4 loading, no boraflex & $1.0895 \pm 0.0008$ & 1.0838 \\
\hline
\end{tabular}

${ }^{\mathrm{a}} 1500$ generations, 500 neutrons per generation.

${ }^{b}$ All bias and uncertainty factors have been removed.

${ }^{\mathrm{c}}$ Boraflex replaced by water.

Table 3. ORNL calculated $k_{\text {eff }}$ values for 3 of 4 loading and 5.65-in. gaps in all boraflex panels

\begin{tabular}{ccc}
\hline Soluble boron $(\mathrm{ppm})$ & Material in gap & $\mathrm{k}_{\text {eff }}{ }^{\mathrm{a}}$ \\
\hline 0 & water & $0.9273 \pm 0.0009$ \\
0 & void & $0.9332 \pm 0.0009$ \\
800 & water & $0.8269 \pm 0.0008$ \\
800 & void & $0.8305 \pm 0.0008$ \\
\hline
\end{tabular}

${ }^{\mathrm{a}} 1500$ generations, 500 neutrons per generation. 


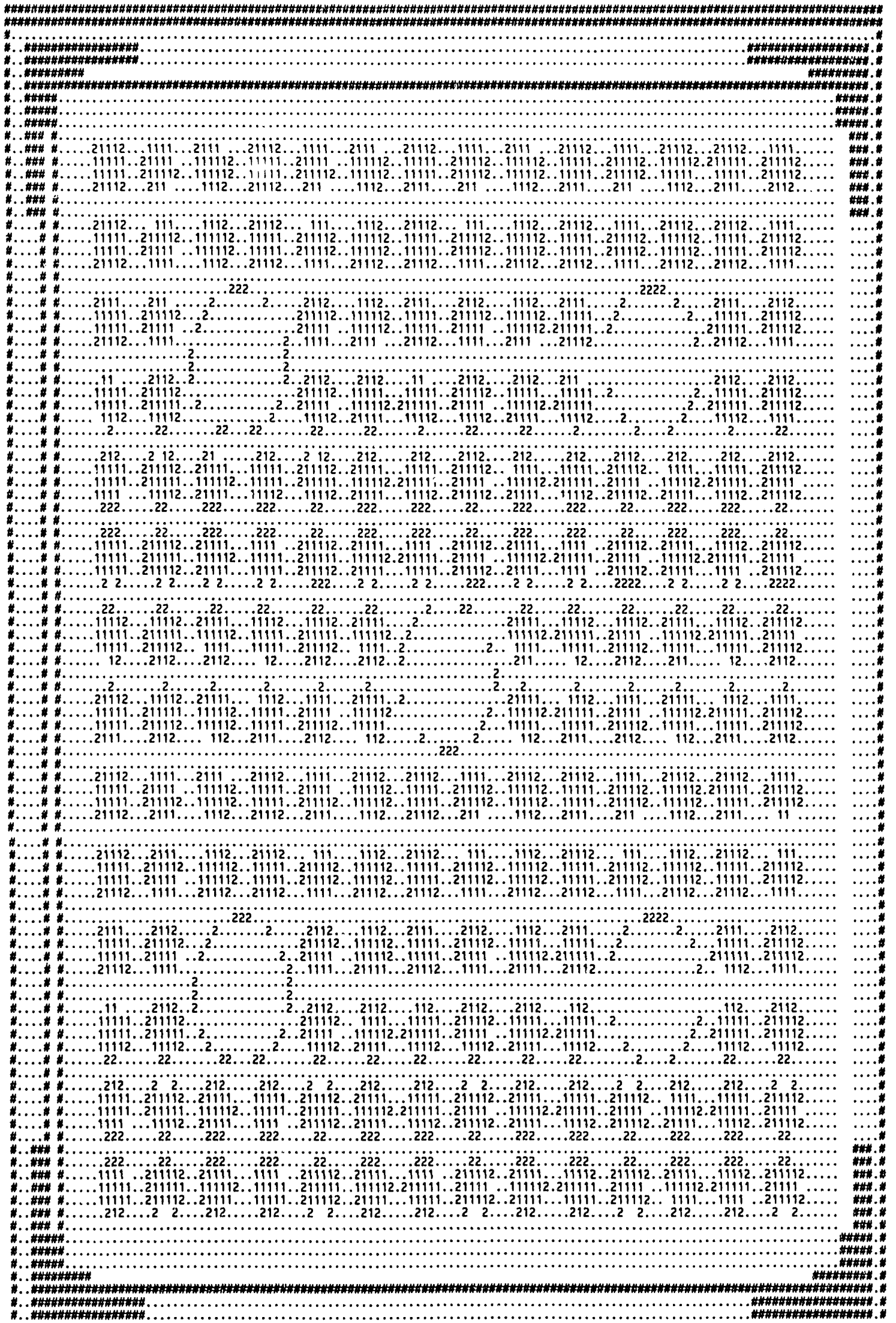

Fig. 2. Printer plot of single fuel assembly. 


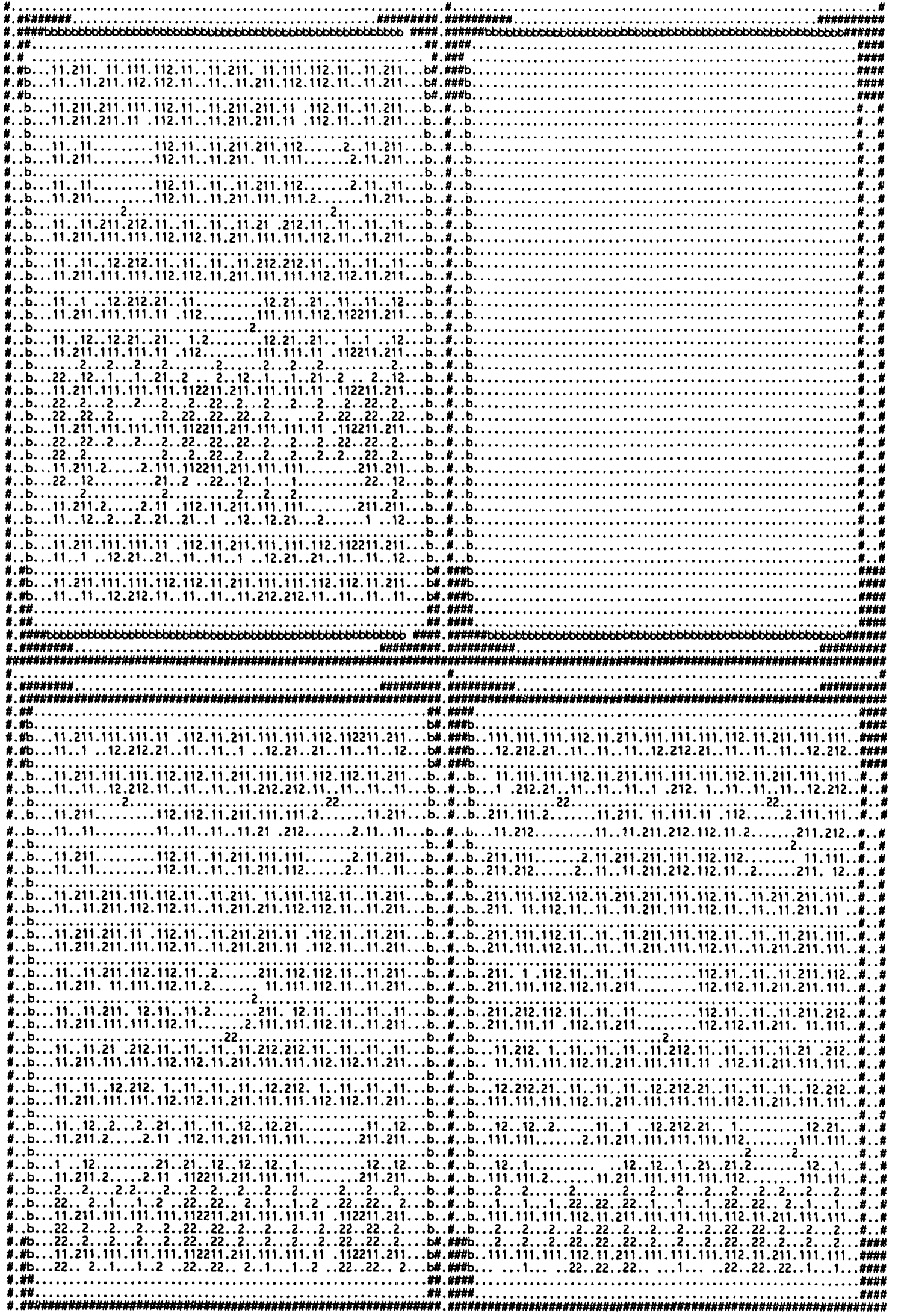

Fig. 3. Printer plot of three of four fuel assembly loading. 


\section{REFERENCES}

1. J. F. Opeka, Northeast Nuclear Energy Company, letter to U.S. Nuclear Regulatory Commission, Facility Operating License No. DPR-65, Docket No. 50-336, B14102, "Millstone Nuclear Power Station, Unit No. 2, Proposed Revision to Technical Specifications Spent Fuel Pool Reactivity," dated April 16, 1992.

2. J. F. Opeka, Northeast Nuclear Energy Company, letter to E. J. Butcher, U.S. Nuclear Regulatory Commission, Facility Operating License No. DPR-65, Docket No. 50-336, B11549, "Millstone Nuclear Power Station, Unit No. 2, Proposed Change to Technical Specifications, Modifications to Spent Fuel Storage Pool," dated July 24, 198.5.

3. J. F. Opeka, Northeast Nuclear Energy Company, letter to U.S. Nuclear Regulatory Commission, Facility Operating License No. DPR-65, Docket No. 50-336, B14138, "Millstone Nuclear Power Station, Unit No. 2, Proposed Revision to Technical Specification, Spent Fuel Pool Reactivity-Correction," dated May 7, 1992.

4. G. S. Vissing, U.S. Nuclear Regulatory Commission, letter to J. F. Opeka, Northeast Nuclear Energy Company, "Issuance of Amendment (TAC No. M83180)," dated June 4, 1992.

5. J. F. Opeka, Northeast Nuclear Energy Company, letter to U.S. Nuclear Regulatory Commission, Facility Operating License No. DPR-65, Docket No. 50-336, B14302, "Millstone Nuclear Power Station, Unit No. 2, Spent Fuel Pool Criticality License Amendment, Response to Request for Additional Information," dated November 24, 1992.

6. Ivan W. Smith, Atomic Safety and Licensing Board, Memorandum and Order, Docket Nos. 50-336-OLA (ASLBP No. 92-665-02-OLA), dated November 24, 1992. 
This page intentionally left blank.

$=$ 


\section{INTERNAL DISTRIBUTION}

1-5. S. M. Bowman

6. L. F. Norris

7-11. C. V. Parks

12. C. H. Shappert

13. R. M. Westfall

14. G. E. Whitesides
15-16. Central Research Library

17. ORNL Y-12 Research Library Document Reference Section

18-19. Laboratory Records Department

20. Laboratory Records, ORNL-RC

21. ORNL Patent Office

\section{EXTERNAL DISTRIBUTION}

22-26. G. H. Bidinger, U.S. Nuclear Regulatory Commission, Office of Nuclear Material Safety and Safeguards, MS 6H3, Washington, DC 20555

27. Office of the Assistarit Manager for Energy Research and Development, U.S. Department of Energy, Oak Ridge Operations, P.O. Box 2001, Oak Ridge, TN 37831

28-29. Office of Scientific anı! Technical Information, P.O. Box 62, Oak Ridge, TN 37831 


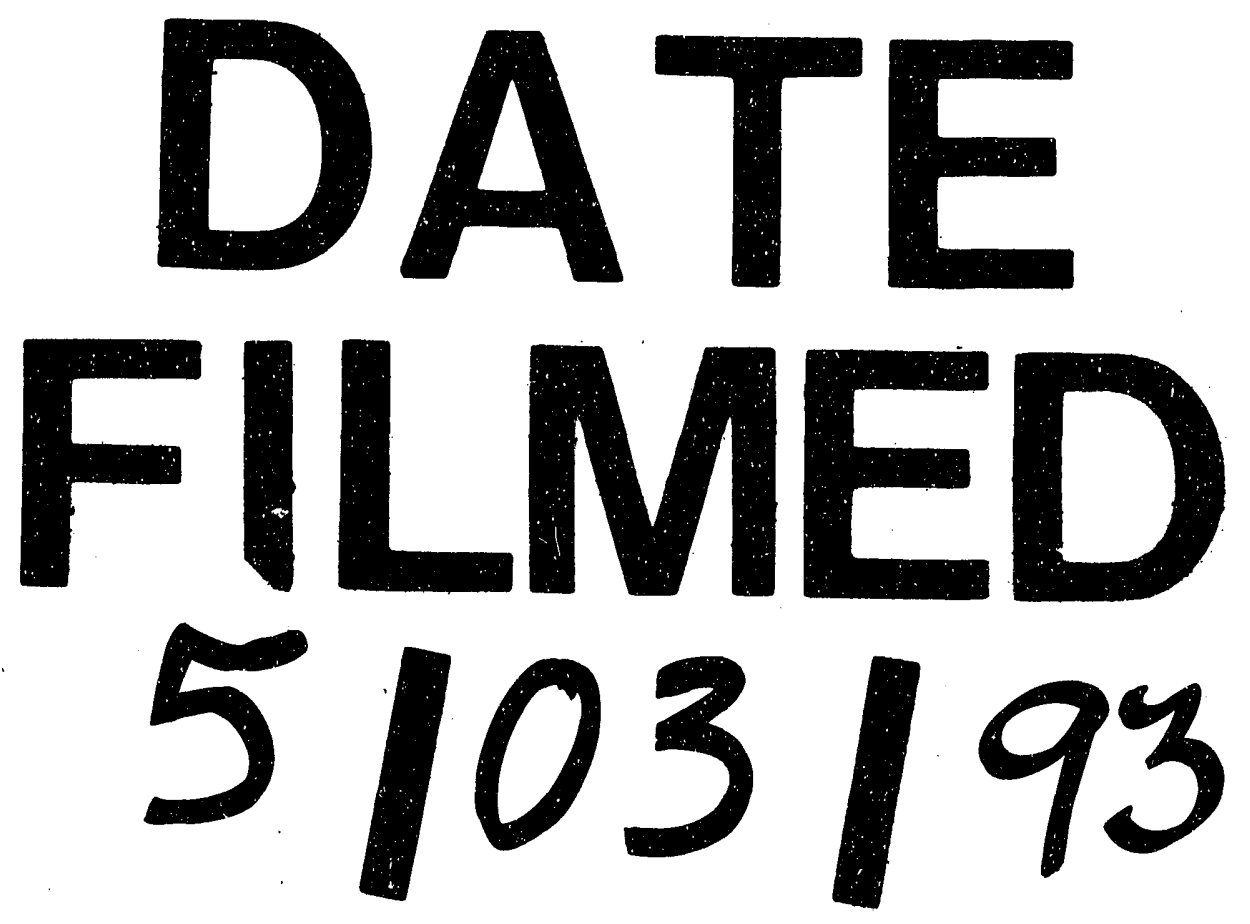


$\cdots$ 